\title{
Microbial Activity in the Agricultural and Forestry System
}

\author{
Ação Microbiana no Sistema Agrícola e Florestal \\ Actividad Microbiana en el Sistema Agrícola y Forestal
}

\author{
Helaine Barros de Oliveira \\ ORCID: https://orcid.org/0000-0001-5560-5187 \\ Universidade José do Rosário Vellano, Brazil \\ E-mail: helaine.oliveira@aluno.unifenas.br \\ Elisa Rocha \\ ORCID: https://orcid.org/0000-0003-3210-0287 \\ Universidade José do Rosário Vellano, Brazil \\ E-mail: elisa.rocha@aluno.unifenas.br \\ Tania Teles \\ ORCID: https://orcid.org/0000-0002-9424-1475 \\ Universidade José do Rosário Vellano, Brazil \\ E-mail: tania.oliveira@aluno.unifenas.br \\ Ligiane Aparecida Florentino \\ ORCID: https://orcid.org/ 0000-0001-9092-3017 \\ Universidade José do Rosário Vellano, Brazi \\ E-mail: ligiane.florentino@unifenas.br
}

\begin{abstract}
Soil quality is directly related to the diversity and density of microorganisms present in it, as they perform important functions that promote the growth of plant species, maintaining soil sustainability and favoring increased agricultural production and environmental regeneration. With this, the objective was to describe and relate the functions of microorganisms existing in the soil and their action potentials in agricultural and forestry species. Some species of fungi and bacteria are able to solubilize phosphorus from phosphate sources, releasing it to be absorbed by plant roots, resulting in gains in crop productivity. Other species of bacteria, when inoculated to seeds, besides stimulating the growth and development of plants, act as biofertilizers by fixing nitrogen from the air (N2). Mycorrhizae constitute a specialized symbiotic association between roots and some soil fungi in which fungal hyphae absorb nutrients from the soil solution and transport them to plants. The inoculation of plant species with microorganisms that help in the availability of phosphorus, due to its low concentration in soils, becomes essential in supplying the nutritional demands of plants and arbuscular mycorrhizal fungi (AMF) and phosphate solubilizing bacteria are among microorganisms that can perform this function. In relation to the main forest species cultivated in Brazil, all have the potential to benefit from associations with microorganisms, hence the importance of knowing, researching and stimulating the increase of the microbial quality of the soil.
\end{abstract}

Keywords: Inoculants; Soil microorganisms; Agroforestry system.

\section{Resumo}

A qualidade do solo está diretamente relacionada com a diversidade e densidade dos microrganismos presentes no mesmo, visto que estes desempenham funções importantes que promovem o crescimento de espécies vegetais mantendo a sustentabilidade do solo e favorecendo o aumento da produção agrícola e regeneração ambiental. Com isso, objetivou-se descrever e relacionar as funções dos microrganismos existentes no solo e seus potenciais de ação em espécies agrícolas e florestais. Algumas espécies de fungos e bactérias são capazes de solubilizar o fósforo das fontes fosfatadas, liberando-o para ser absorvido pelas raízes das plantas resultando em ganhos na produtividade das culturas. Já outras espécies de bactérias ao serem inoculadas às sementes além de estimularem o crescimento e desenvolvimento das plantas, atuam como biofertilizantes ao fixarem o nitrogênio do ar $\left(\mathrm{N}_{2}\right)$. As micorrizas constituem uma associação simbiótica especializada entre raízes e alguns fungos do solo em que as hifas fúngicas absorvem nutrientes da solução do solo transportando-os para as plantas. A inoculação de espécies vegetais com microrganismos que auxiliem na disponibilidade de fósforo, devido à baixa concentração do mesmo nos solos, tornase imprescindível no suprimento das demandas nutricionais das plantas e os fungos micorrízicos arbusculares (FMAs) e as bactérias solubilizadoras de fosfato estão entre os microrganismos que podem desempenhar essa função. Em relação às principais espécies florestais cultivadas no Brasil, todas têm potencial de se beneficiarem com as associações com microrganismos, daí a importância de se conhecer, pesquisar e estimular o aumento da qualidade microbiana do solo.

Palavras-chave: Inoculantes; Microrganismos do solo; Sistema agroflorestal. 


\begin{abstract}
Resumen
La calidad del suelo está directamente relacionada con la diversidad y densidad de microorganismos presentes en él, ya que cumplen importantes funciones que favorecen el crecimiento de las especies vegetales, manteniendo la sostenibilidad del suelo y favoreciendo el aumento de la producción agrícola y la regeneración ambiental. Con esto, el objetivo fue describir y relacionar las funciones de los microorganismos existentes en el suelo y sus potenciales de acción en especies agrícolas y forestales. Algunas especies de hongos y bacterias pueden solubilizar el fósforo de las fuentes de fosfato, liberándolo para que lo absorban las raíces de las plantas, lo que genera ganancias en la productividad de los cultivos. Otras especies de bacterias, cuando se inoculan a las semillas, además de estimular el crecimiento y desarrollo de las plantas, actúan como biofertilizantes al fijar nitrógeno del aire $\left(\mathrm{N}_{2}\right)$. Las micorrizas constituyen una asociación simbiótica especializada entre las raíces y algunos hongos del suelo en la que las hifas fúngicas absorben los nutrientes de la solución del suelo y los transportan a las plantas. La inoculación de especies vegetales con microorganismos que ayudan en la disponibilidad de fósforo, debido a su baja concentración en los suelos, se vuelve fundamental para suplir las demandas nutricionales de las plantas y los hongos micorrízicos arbusculares (HMA) y las bacterias solubilizadoras de fosfato se encuentran entre los microorganismos que pueden realizar esta función. función. En relación a las principales especies forestales cultivadas en Brasil, todas tienen potencial para beneficiarse de asociaciones con microorganismos, de ahí la importancia de conocer, investigar y estimular el aumento de la calidad microbiana del suelo.
\end{abstract}

Palabras clave: Inoculantes; Microorganismos del suelo; Sistema agroforestal.

\title{
1. Introduction
}

In recent decades, population growth and technological development increased the demand and pressure on natural resources. In Brazil, high deforestation rates have generated scenarios of environmental degradation (Brasil, 2018; Marques, 2016; Oliveira et al., 2021). Hence, the maintenance of soil sustainability is considered a key factor for reforestation and environmental regeneration. Thus, the concept of soil quality has been changing, concerning not only soil fertility but also the microorganisms present in it and their diversity. Studies show that using soil microorganisms can be efficient and inexpensive, acting in the biocontrol of pathogens and promoting plant growth, but its practical application is still restricted (Oliveira et al., 2020).

The positive effect of these microorganisms on soil and plants has already been proven by several studies (Moreira \& Siqueira, 2006; Leal et al., 2021), demonstrating the importance of using commercial inoculants. Thus, the use of growthpromoting microorganisms can accelerate plant development, increase nutrient availability, contribute to soil fertility management, and favor plant growth and development.

Among some examples of the application of microorganisms in agrosilvopastoral activities, we can emphasize fungi of the genus Trichoderma, which constitute one of the main groups of microorganisms of importance for plant development (Chagas et al., 2017). The beneficial action of rhizobacteria is also discussed by Lopes et al. (2018), who report increases in physiological, morphological, and biochemical variables in Brachiaria (Syn. Urochloa) brizantha cv. BRS Piatã inoculated with Pseudomonas fluorescens (BRM32111) and Burkholderia pyrrocinia (BRM32113). The inoculation of young açaí plants with Bacillus thuringiensis YBT-1518 and Pseudoruegeria sabulilitoris strain GJMS-35, promoted an increase in growth, biomass accumulation, higher nutrient contents as well as improvements in physiological parameters when compared to the control treatment (Castro, 2018).

In addition, species of fungi and bacteria can solubilize phosphorus bound to iron and aluminum oxides, releasing it into the soil solution to be absorbed by plant roots (Ribeiro et al., 2018). Consequently, it improves the efficiency of rock phosphates and offers an alternative to soluble sources. Therefore, resulting in gains in crop productivity.

Hence, it appears that soil management in agriculture is essential for its high fertility and consequently for increasing plant production. Although the use of chemical fertilizers and pesticides is a common practice for agricultural activity, it can generate a decrease in soil biodiversity resulting in environmental pollution, one of the main concerns for sustainability 
(Kuroda et al., 2020). Considering the above, the objective of this review was to highlight the functions of soil microorganisms and relate their potential use in agricultural and forestry species.

\section{Methodology}

A literature review was carried out using publications from the Science Direct, Scopus, Wiley Online Library and Scientific Electronic Library Online (Scielo) databases, using the following descriptors: "soil microbiology", "soil microorganism functions", "growth promoting microorganisms". plant", "atmospheric nitrogen fixing bacteria", "mycorrhizal fungi", "application microorganisms to agriculture", "inoculants", "agricultural sustainability", "silviculture sustainability".

Articles from 1967 to 2021 were selected for the elaboration of the review with an emphasis on microbial action in the agricultural and forestry system. The oldest articles were used because they address important information that allows analyzing the process of selection of microorganisms for agricultural and forestry use.

\section{Results and Discussion}

\section{Microorganism-Plant Interactions}

According to Moreira and Siqueira (2006), some species of bacteria, when applied to seeds or roots, stimulate the growth and development of plants. They also promote the penetration of roots into the soil during germination or influence the symbiosis between other microorganisms with the plant, in addition to acting as biofertilizers by fixing nitrogen $\left(\mathrm{N}_{2}\right)$ from the air, as phytostimulants by inducing the plant to produce hormones (Vessey, 2003) and decreasing the inhibition of pathogens on plant development (Glick, 2012).

Other associated microorganisms are mycorrhizae, defined as a specialized symbiotic association between roots and some soil fungi. Through this interaction, the plant provides the fungus with carbohydrates necessary for its development, while the fungus, with its hyphae, helps absorb nutrients from the soil solution (Smith \& Read, 1997). The absorption and transfer of macronutrients, such as Nitrogen $(\mathrm{N})$ and Phosphorus (P), and of micronutrients as Zinc (Zn), is slow. Mycorrhizas are not associated with pioneer species, for the most part, as they have fast-growth and require the immediate availability of nutrients. The presence of mycorrhiza makes plants less susceptible to pathogenic fungi attacks.

According to Souza et al. (2005), mycorrhizas increase growth and resistance to the plant under adverse conditions, such as higher temperature, soil acidity, water stress, and tolerance to root pathogens and toxic substances present in the soil. Without ectomycorrhizas, P-uptake can be halved compared to roots with these microorganisms.

The foremost symbiotic associations between microorganisms and forest species are ectomycorrhizas (as in Pinus spp.) and endomycorrhizas (in different tropical and subtropical species, as Bactris gasipaes and Araucaria angustifolia). Also, N-fixing bacterial nodules (characteristic of legumes), and non-bacterial nodules N-fixers, especially from actinomycete fungi.

According to Moreira and Siqueira (2006), ectomycorrhizas present an intercellular penetration of the cortex, where exchanges between the fungus and the plant occur through a hyphal mantle external to the root. In arbuscular mycorrhizae (endomycorrhizae), the hyphae have intracellular penetration and form arbuscules, favoring the exchanges. Also, there is no external mantle of hyphae or morphological changes in the roots.

Ectomycorrhizas are economically important for the forestry sector. However, they occur in a restricted group of plants (approximately 5\%) (Bellei \& Carvalho, 1992). Endomycorrhizae can colonize most known plant species (about 90\% of plants of agronomic and forestry interest), according to Trappe (1987). 
According to Molina (1981), some species can form associations with more than one type of microorganism, for instance, Alnus spp. (ectomycorrhizas and fungal nodules), Casuarina spp. (endomycorrhizas and fungal nodules) (Bowen, 1980), Eucalyptus (endomycorrhizas and ectomycorrhizas), and Leucaena leucocephala (bacterial nodules and endomycorrhizas).

According to Chu et al. (2001), arbuscular mycorrhizal fungi (AMF) are widely found in tropical ecosystems and are extremely important for tropical forests, as they have poor soil with low availability of nutrients. Some environmental factors can influence the formation of mycorrhiza in these environments, such as nutrient availability, temperature, water availability, soil $\mathrm{pH}$, light intensity, host plant physiology, the toxicity of some pesticides, and interactions with soil microorganisms. Arbuscular mycorrhizae are important in the initial phase of forest species development and are gradually replaced by ectomycorrhizal fungi (Santos, 2006). According to Dias et al. (2012), one of the benefits of microorganisms is that they promote better seedling growth and increase in root biomass compared to uninoculated seedlings.

\section{Biological Nitrogen Fixation}

Biological nitrogen fixation (BNF) is performed through the nitrogenase enzyme present exclusively in diazotrophic bacteria, transforming $\mathrm{N}_{2}$ into ammonia (Moreira \& Siqueira, 2006). They also reduce the need for chemical fertilizers (Bosa et al., 2016).

$\mathrm{N}$ is an essential nutrient for the development of plants and soil microbiota. This element is found on a large scale in the atmosphere, and plants obtain it via enzymatic activity through fixing bacteria (Santachiara et al., 2019), converting it into ammonia $\left(\mathrm{NH}^{4+}\right)$, and nitrate $\left(\mathrm{NO}^{3-}\right)$, assimilated by plants (Gebremedhin, 2018).

Soil conditions can influence the presence of microorganisms and inhibit their activities (Moreira \& Siqueira, 2006). Studying the intimate relationships between microorganisms and the soil is of paramount importance to evaluate the biological processes involved in the microbiota, where external factors such as soil acidity (Florentino et al., 2015) and biotic and abiotic stresses can influence its microbial activity and presence, interfering with BNF.

According to Martins et al. (2020), BNF has contributed significantly to the addition of fixed $\mathrm{N}_{2}$ in sugarcane crops, with a considerable difference between inoculated versus non-inoculated cultures, with yields being 205 to $215 \mathrm{~kg} \mathrm{~N}$ ha ${ }^{-1}$ and 139 to $166 \mathrm{~kg} \mathrm{~N}$ ha- $^{-1}$, respectively.

\section{Microorganisms in forest species}

According to Lagos and Muller (2007), the Atlantic Forest is among the five main biomes of the planet's biodiversity hotspots and is characterized by its high species diversity and endemism. Therefore, there is a concern to prioritize its conservation. But currently, it has few extensive areas, mainly in the south and southeast regions of Brazil, presenting a considerable volume of fragments in various stages of degradation. According to Moreira and Siqueira (2006), planting forest species is important for the protection, recovery, or recomposition of degraded areas, as they fulfill a relevant function of protecting biodiversity, preventing, and controlling fires, protecting water and soil, in addition to carbon capture.

Hence, the presence of some native and cultivated species that are under intense exploration, such as Pinus, Eucalyptus, and Araucaria, stands out. The latter is a native species, in the late 1980s, it reached the point of exhaustion of its natural reserves and is currently considered vulnerable to extinction.

According to the Brazilian Tree Industry (2016), exotic species, for instance, Pinus and Eucalyptus, are the main genera of species planted in Brazil because of the edaphoclimatic conditions that allow outstanding growth in different locations. They correspond to about 20 and $72 \%$ of the planted area, totaling 7.2 million hectares in 2015 . With the advent of tax incentives in the 60s and 70s, according to Siqueira (2003), the planting of Pinus and Eucalyptus species had begun in the 
country, specifically in the South region, corresponding to $26 \%$ of the total area planted with these genera in the country (Indústria Brasileira de Árvores, 2016). Thus, it is demonstrated the importance of pine in the wood production chain, especially in the national economy, as it provides the raw material for the wood, furniture, and pulp and paper sectors (Canei et al., 2018).

Given the importance of planting these species and the need to reforest, studies have demonstrated the significance of knowing the microbiological attributes of soils (Baretta et al., 2005; Batista et al., 2007). Microorganisms can increase the production and by the constant cycling of nutrients and availability of chemical elements, allow plant species to be reestablished (Moreira \& Siqueira, 2006).

The sites in Brazil used for reforestation programs usually have low fertility. To recover a degraded area, fast-growing forest species that are aggressive to cover the soil are the first choice, as they provide better deposition of organic material and nutrients. That is why the symbiotic associations between microorganisms and forest species are relevant to be studied because they represent a field with vast potential for occupying marginal lands and increasing productivity. A notable example is the inoculation of pure cultures of the ectomycorrhizal fungus Pisolithus tinctorius in Pinus nurseries ("Southern pines") in the United States, therefore, increasing the growth in usual planting sites and allowing to revegetate mining areas, where other attempts with Pinus had failed (Molina, 1977). The main native species used for reforestation in Brazil are:

\section{Parana Pine (Araucaria angustifolia (Bert.) O. Ktze.)}

Araucaria has short and rounded radicles without absorbent hairs (Zandavalli et al., 2008). The author also evaluated the presence of endomycorrhizas in the Paraná pine, and cortical cells were also observed full of fungi, whose hyphae are from their tiny nuclei.

\section{Palm (Euterpe edulis Mart.)}

According to Janos (1976), the symbiotic associations between palm plants and microorganisms probably occur due to the presence of endomycorrhizae, as observed in other palm trees.

\section{Legumes}

To reforest, vegetation that covers the degraded soil is needed. Thus, promoting the rapid regeneration of its chemical and physical characteristics. Therefore, tree or shrub species belonging to the leguminous family, which can fix nitrogen through symbiosis with bacteria of the genus Rhizobium, should be used as vegetation cover on soil. Symbiosis occurs in the nodules of the superficial roots of the plants. If the bacteria are not indigenous, they must be introduced using specific inoculum added to the seeds (Poggiani et al., 1981). The nitrogen contribution of legumes is important to maintain soil productivity for long periods. In addition, it allows the subsequent planting of other forest species.

According to Dobereiner (1967), although in the native and planted forests nodulation and $\mathrm{N}_{2}$ fixation are observed, there are possibilities of accelerating the establishment of seedlings in the field through inoculation of selected Rhizobium strains. In Brazil, the most common practice is to fertilize forest seedlings with NPK, and the application of mineral N impairs the formation of nodules. Seedlings of plant species fertilized only with PK and, therefore, well nodulated, showed an increase in development from 52 to $94 \%$, and twice the growth rates at the time of transplantation, compared with treatments with NPK and no nodules. Simple inoculation with nodules more than doubled nitrogen fixation in bracatinga ponds (Poggiani et al., 1981).

The main forest species cultivated on a commercial scale in our country are in the South Region, are, for instance, Eucalyptus spp., Pinus spp., and Acacia mearnsii de Wild. They all have symbiotic associations with microorganisms. 


\section{Pinus spp.}

Ectomycorrhiza fungi are among the essential factors that determine the productivity of Pinus species in Brazil, and their beneficial effect on the growth of forest trees, is already well known (Marks \& Kozlowski, 1973). That is why it is necessary to handle these fungi under Brazilian conditions since they are not native to Brazilian soils.

According to Deichmann (1967), most pine species that grow in Brazil are only successfully cultivated if mycorrhiza exists in the soil. If the correct type of mycorrhiza is not present, the pond soil should be inoculated.

New techniques for mycorrhizal fungi in pine reforestation programs have been developed through selected fungi inoculum incorporated in fumigated soil in seedling nurseries. Because of its adaptation to different environmental conditions, easy growth, and efficient dissemination, the most frequently used fungi are Pisolithus tinctorius and Thelephora Terrestris.

\section{Eucalyptus spp.}

Symbiotic associations between many eucalyptus species occur with endo or ectomycorrhizal fungi. In the case of Pinus spp, there is no absolute requirement for its inoculation in nurseries. When eucalyptus species are associated with ectomycorrhizal fungi, it is beneficial for its development. Although the influence on silvicultural behavior is still not well understood, Eucalyptus species differ in terms of the dependence of the symbiotic association, with endo and ectomycorrhizal fungi.

\section{Black Wattle (Acacia mearnsii de Wild)}

Artificial inoculation is not usually performed in Black Wattle nurseries. Therefore, it relies on the spontaneous nodulation of this species by Rhizobium.

According to Muniz et al. (2007), studies related to microorganisms in forest species focus on the seedling production system, a fundamental activity in the productive process of the forest sector. But this production has some compromising factors, such as its sanitary origin, due to the large number of pathogens associated with the seeds and, later, the resulting seedlings.

According to Sales (1992), an essential germination factor is the sanitary quality of seeds of forest species due to losses through deterioration, abnormalities, seedling injuries, and a drastic reduction in seedling production in nurseries, in addition to the increased costs to reforest.

Botelho (2006) pointed out that some researchers when doing sanity tests on native forest seeds found that fungicides, such as Captan, showed satisfactory results in reducing most fungal genera. Increasing, therefore, the total number of germinations from seeds previously treated (Martins-Corder \& Borges Júnior, 1999).

An efficient control measure is to treat the seeds, aiming to reduce future diseases in forest species since information regarding the health of the seeds of many species of high economic value is scarce.

\section{Inoculants}

According to Carneiro et al. (2012), to better control and maintain the environmental quality and to recover of degraded areas, the use of existing soil microorganisms is highlighted for being efficient and contributing to the increase of the availability of nutrients in the soil, favoring the growth of plant species. If the ecological relationships and nutritional requirements of the species are known, it helps the development of technologies to obtain healthy seedlings for reforestation programs.

The inoculation of plant species with microorganisms that help in the availability of phosphorus, due to its low availability in soils, becomes essential in supplying the nutritional demands of plants. Arbuscular mycorrhizal fungi (AMF) 
and phosphate-solubilizing bacteria are among these microorganisms. The AMF promotes $\mathrm{P}$ absorption through a network of hyphae that increase the surface for exploration of the soil by the roots. However, phosphate-solubilizing bacteria act differently, secreting exudates that dissolve molecules containing phosphorus, promoting their availability for plants' roots. Thus, it results in the beneficial effect of microorganisms in the processes of recovery of degraded areas (Pasqualini, 2013).

Currently, Brazil is recognized worldwide for its systematic organization of an entire policy of research and production of inoculants. All stages from development to field use are specified, proven, and defined through strong legislation, as follows: Law $\mathrm{n}^{\circ} 6.894$ (12/16/1980) and the amendment to Law $\mathrm{n}^{\circ} 6.934$ (07/13/1981) that regulates the inspection and examination of the production and trade of fertilizers, correctives, inoculants, stimulants or biofertilizers; MAPA Regulation $N^{\circ} .53$ (10/23/2013) which provides for classification, records, packaging, labeling, advertising, service provision, procedures, inspection, an inspection of production, import, export, and trade of fertilizers, correctives, inoculants, biofertilizers, and secondary materials; Normative Instruction SDA n ${ }^{\circ} 13$ (24/03/2011) that presents norms to specify, register, pack and label the inoculants destined to the agriculture, and the list of authorized and recommended microorganisms for their production in Brazil.

According to Normative Instruction SDA No 13 (24/03/2011), there are microorganisms recommended to produce inoculants for eucalyptus in Brazil, one of the most cultivated forest species for reforestation, as shown in the Table 1.

Table 1. Microorganisms recommended for inoculants production for eucalyptus.

\begin{tabular}{lllcl}
\hline Specie & Common name & Genus/specie & Original designation & Responsible institution \\
\hline Eucaliptus $\mathrm{sp}$. & Eucalyptus & Bacillus subtilis & UFV 3918 & Universidade Federal de Viçosa \\
Eucaliptus $\mathrm{sp}$. & Eucalyptus & Frauteria aurantia & UFV R1 & Universidade Federal de Viçosa \\
Eucaliptus $\mathrm{sp}$. & Eucalyptus & Bacillus subtilis & UFV S1 & Universidade Federal de Viçosa \\
Eucaliptus $\mathrm{sp}$. & Eucalyptus & Bacillus subtilis & UFV S2 & Universidade Federal de Viçosa \\
\hline
\end{tabular}

Source: IN (2011).

Regarding the evaluation of the viability and agronomic efficiency of strains, inoculants, and inoculation technologies, the parameters to evaluate for forest species are the followings: Production of plant biomass, which can be shoots or roots, according to the crop specification; the height of plants; stem diameter; seedling survival, and other parameters suitable for evaluating the efficiency of the process under study (Normative Instruction, 2011).

To control mycorrhization, it is necessary to develop methods to produce inoculants on a large scale. Several types of ectomycorrhizal inoculants have been used, such as the vegetative inoculant and spores. The inoculant consists of the mycelium in pure culture in a vermiculite-peat-culture medium mixture (Alves et al., 2001). The most widely used AMF inoculum methods are the on-farm production method (with substrates), the method without substrate (aeroponics and hydroponics), and the in vitro system with modified plants and roots (Pasqualini, 2013).

According to Douds. et al. (2005), the on-farm inoculant can be produced under natural environmental conditions and does not require a specific structure. Thus, it multiplies AMF species with an efficiency that may or may not be known in a given area. In Brazil, Schlemper and Stürmer (2014) used non-composted lignocellulosic residues, mixed in rice husk, soil, and pre-colonized plants of Sorghum bicolor, to produce the mycorrhizal inoculant on-farm (Czerniak \& Sturmer, 2014).

According to Pasqualini (2013), the on-farm method has some advantages, for instance: the relatively low cost, as the necessary resources are easily accessible and cheap, it is a manual production system that can be implemented with a 
consortium of AMF species or an isolated species, it is capable of producing a large amount of AMF inoculum in a small space, there is the possibility of controlling the nutrition of fungi and plants when the substrate is inert, and the inoculum production is highly adaptable to the site. We can highlight some disadvantages, as the difficulties of the method to guarantee the absence of contaminants, even with strict control of the system, it can present pest attack to the plants, the final inoculum may present difficulties in preparation, and application in large areas, mainly through mechanical methods.

The production method without substrate is developed to be relatively free of contaminants. However, it has a high cost, being used mainly to produce small quantities of the inoculum and for research purposes. This method is classified into aeroponic and hydroponic, and their differences are related to the application of nutrients. According to Marleen et al. (2011), in the hydroponic system, the solution containing the necessary nutrients must be available through a system of aeration pumps to prevent the roots from running out of oxygen.

According to Zobel et al. (1976), in the aeroponics system, both roots and AMFs undergo a nutrient solution. It is essential to maintain a minimum amount of this solution so that the plant metabolism does not decrease, regardless of the nutrient availability system. That's why the nutrient solution must be frequently renewed or when nutrient levels are below the minimum requirement. In this technique, the plants must be pre-colonized before being introduced into the system. The precolonization must occur with the addition of infective propagules (roots, spores, hyphae) in a previously sterilized substrate, which can serve as a support for the growth and development of plants that are usually in pots.

According to Sylvia and Jarstfer (1994), despite being a relatively new method, it already demonstrates some advantages and disadvantages. For instance, the production of substrates free of particle adhesion, the crush of roots, and the inoculum with a high density of propagules and a low risk of cross-contamination with other fungi. Being, therefore, able to control and manipulate the supply of nutrients and $\mathrm{pH}$ to the host. The lack of a support substrate can affect the spore production rate. Also, fast root growth in the solution can cause low AMF colonization and high cost because it needs a closed place with good infrastructure.

The third production method is in vitro, which bases on the culture of AMFs with modified roots. The culture media for the in vitro system must have micro and macronutrients, vitamins, and sucrose. They are solidified using Phytagel (Sigma) or GelGro (MP Biomedicals). However, in the multiplication system with the whole plant, the use of vitamins and sucrose is not necessary because photosynthesis helps to obtain those elements.

As an advantage of this method, it is possible to cite the absence of undesirable microorganisms, which makes it a safe and adequate system to produce the inoculum on a large scale and with high quality. Also, the space for multiplication is reduced because it uses plates and chambers. In addition, it is possible to produce a high quantity of spores in a short period, and the time of harvest can be determined once the sporulations can be monitored. Regarding the disadvantages, the technique requires a high cost and specialized technicians, the application system is inconvenient for the field, and in vitro plant cultures need continuous monitoring and supply of nutrients, increasing the risk of contamination (Pasqualini, 2013).

The large-scale production of mycorrhizal inoculants is relevant, regardless of the method, if it guarantees infectivity and the establishment of a symbiotic relationship. The mycorrhizal inoculum will benefit agricultural and forestry producers since the multiplied AMF species are selected for later inoculation both commercially and in crop production. Hence, the process of nutrient absorption by plants, especially phosphorus, will be higher, increasing growth and productivity.

The phosphate-solubilizing microorganisms are represented by bacteria and fungi, with bacteria ranging from 1 to $50 \%$ and fungi from 0.5 to $1.0 \%$ of the total (Kucey, 1983). Several bacterial genera such as Pseudomonas, Burkholderia, Rhizobium, Bacillus, Agrobacterium, Azotobacter, and Erwinia were studied and presented the ability to solubilize, making them useful in agricultural systems (Verma et al., 2001). The inoculation of phosphorus-solubilizing bacteria or the management of their population provides many benefits to plant development, thus improving the supply of phosphorus (Terra 
et al., 2019) and ensuring greater competitiveness and survival of plants, especially in recovery areas, since they have a low supply of nutrients.

The action of AMFs also contributes to enhancing soil properties in stressed environments (Ortega-Larrocea et al., 2010) and plays an important role in plant growth through fungal hyphae, increasing water, and nutrient absorption surfaces through root extensions (Pasqualini, 2013). In addition to improving phosphorus absorption by plants.

Many studies related to the use of inoculants have focused on the fungus of the genus Pisolithus, as it colonizes a wide variety of hosts (Souza, 2000). Pisolithus is a cosmopolitan ectomycorrhizal fungus, with a cap 30 or basidiome with a diameter between 2.4 and $8 \mathrm{~cm}$, with a globose or piriform morphology, and an extensive and robust pseudo stipe, which can reach up to $7.7 \mathrm{~cm}$ in length and $3 \mathrm{~cm}$ in thickness. Internally, the hymenium structure stores the spores, and when young, the peridium presents colors that vary from straw to matte black.

However, upon reaching maturity, the peridium is degraded, varying from olive green to black (Mamede, 2015). In culture, it grows slowly, with cottony mycelium and a light brown color. They live in symbiosis with several species of trees, mainly with Angiosperms and Gymnosperms, stimulating their growth (Souza et al., 2004). This symbiosis is of great importance for the host trees, as the fungal partner improves the absorption and transport of water and nutrients from the soil, increases tolerance to acidity, to the toxicity of heavy metals, to elevated soil temperatures, and provides increased resistance to diseases of the root system.

\section{Final Considerations}

Because of population growth and technological advances, natural resources have been misused. Therefore, maintaining soil sustainability is one of the main factors to increase soil fertility, and microorganisms play a key role in this process.

Thus, the concept of soil quality is changing. Therefore, being limited not only to its fertility but also to the microorganisms and their diversity. The use of soil microorganisms can be efficient and low-cost, acting in the biocontrol of pathogens and plant growth promotion, but its practical application needs to be widespread.

\section{Acknowledgment}

The authors thank CAPES and FAPEMIG for their financial support.

\section{References}

Alves, J. R., Souza, O., Podlech, P. A., Giachini, A. J. \& Oliveira, V. L. (2001). Efeito de inoculante ectomicorrízico produzido por fermentação semi-sólida sobre o crescimento de Eucalyptus dunnii Maiden. Pesquisa Agropecuária Brasileira, 36 (2), 307-313.

Baretta, D., Santos, J. C. P., Figueiredo, S. R. \& Klauberg-Filho, O. (2005). Efeito do monocultivo de Pinus e da queima do campo nativo em atributos biológicos do solo no Planalto Sul-Catarinense. Revista Brasileira de Ciência do Solo, 29 (5), 715-724.

Batista, M., Kliemann, H. J., Silveira, P. M. S \& Lanna, A. c. (2007). Atributos biológicos do solo sob influência da cobertura vegetal e do sistema de manejo. Pesquisa Agropecuária Brasileira, 42 (12), 1755-1761.

Bellei, M. M. \& Carvalho, E. M. S. (1992). Ectomicorrizas. In: Cardoso, E. J. B. N., Tsai, S. M. \& Neves, M. C. P. Microbiologia do Solo. Campinas, Sociedade Brasileira de Ciência do Solo, Cap. 21, p. 297-318.

Bosa, C. K., Guimarães, S. L., Polizel, A. C., Bonfim-Silva, E. M., \& Canuto, E. L. (2016). Características produtivas e nutricionais do capim-xaraés inoculado com bactérias diazotróficas associativas. Arquivo Brasileiro de Medicina Veterinária e Zootecnia, 68 (5), $1360-1368$.

Botelho, L. S. (2006). Fungos associados às sementes de ipê-amarelo (Tabebuia serratifolia), ipê-roxo (Tabebuia impetiginosa), aroeira pimenteira (Schinus terebinthifolius) e aroeira-salsa (Schinus molle): incidência, efeitos na germinação, transmissão para plântulas e controle. 2006. (Mestrado em Agronomia)Universidade de São Paulo- Escola Superior de Agricultura "Luiz de Queiroz", Piracicaba, 114 p.

Bowen, G. D. (1981). Mycorrhizal roles in tropical plants and ecosystems. In: Mikola, P. (ed.). Tropical micorriza research. Oxford, Clarendon Press, p. 165202. 
Brasil. Instituto Nacional de Pesquisa Espacial. PRODES. (2018). Taxas anuais de desmatamento na Amazônia Legal Brasileira.

Canei, A. D., Hernández, A. G., Morales, D. M. L., Silva, E. P., Souza, L. F., Loss, A., Lourenzi, C. R., Reis, M. S. \& Soares, C. R. F. S. (2018). Atributos microbiológicos e estrutura de comunidades bacterianas como indicadores da qualidade do solo em plantios florestais na mata atlântica. Ciência Florestal, 28(4), 1405-1417.

Carneiro, R. F. V., Cardozo Júnior, F. M., Pereira, L. F., Araújo, A. S. F. \& Silva, G. A. (2012). Fungos micorrízicos arbusculares como indicadores da recuperação de áreas degradadas no Nordeste do Brasil. Revista Ciência Agronômica, 43 (4), 648-657.

Castro, G. L. S. (2018). Rizobactérias promovem crescimento, aliviam os efeitos do déficit hídrico e reduzem antracnose em mudas de açaizeiro. Tese (Doutorado em Agronomia). Universidade Federal Rural da Amazônia, Belém.

Chagas, L. F. B., Junior, A. F. C. \& Castro, H. G. (2017). Phosphate solubilization capacity and indole acetic acid production by Trichoderma strains for biomass increase on basil and mint plants. Brazilian Journal of Agriculture, 92 (2), 176- 185.

Chu, E.Y., Möller, M.R.F. \& Carvalho, J.G. (2001). Efeitos da inoculação micorrízica em mudas de gravioleira em solo fumigado e não fumigado. Pesquisa Agropecuária Brasileira, Brasília, 36 (4), 671-680.

Martins-Corder, M. P. \& Borges Junior, N. (1999). Desinfestação e quebra de dormência de sementes de Acacia mearnsii de Wild. Ciência Florestal, 9 (2), 17.

Czerniak, M. J. \& Sturmer, S. L. (2014). Produção de inoculante micorrízico on farm utilizando resíduos da indústria florestal. Revista Brasileira de Ciência do Solo, 38 (6), 1712-1721.

Deichmann, V. V. (1967). Noções sobre sementes e viveiros florestais. Curitiba, Universidade Federal do Paraná. 196 p.

Dias, P. C., Perreira, M. S. F., MegumiKasuya, M. C., Paiva, H. N., Oliveira, L. S. \& Xavier, A. (2012). Micorrizas arbusculares e rizóbios no enraizamento e nutrição de mudas de Angico-Vermelho. Revista Árvore, 36 (6), 1027-1037.

Dobereiner, J. (1967). Efeito da inoculação de sementeiras de sabiá (Mimosa caesalpiniaefolia) no estabelecimento e desenvolvimento das mudas no campo. Pesquisa Agropecuária Brasileira, 2 (1), 301-305.

Douds, D. D,, Nagahashi, G., Pfeffer, P. E., Kayser, W. M. \& Reider, C. (2005). On-farm production and utilization of arbuscular mycorrhizal fungus inoculum. Canadian Journal of Plant Science, 85 (1), 15- 21.

Florentino, L. A., Nunes, A. P. P., Rezende, A. V., Mantovani, J. R., Souza, F. R. C. \& Junqueira, G. A. (2015). Ocorrência e eficiência do microssimbionte de Sesbania virgata (Cav.) Pers. em função das propriedades do solo. Revista de Ciências Agrárias, 38 (4), 528-534.

Gebremedhin, W. (2018). Summary note on nitrogen fixation, legume nodulation and abiotic factors affecting biological nitrogen fixation inside the soil. Advances In Life Science And Technology, 55 (1), 55-60.

Glick, B. R. (2020). Plant Growth-Promoting Bacteria: Mechanisms and Applications. Hindawi Publishing Corporation, Scientifica.

IBÁ - Indústria Brasileira de Produtores de Árvores. Relatório IBÁ $2016 \quad$ ano base $2015 . \quad$ Brasília: $2016 . \quad 100 \quad$ p. http://iba.org/images/shared/Biblioteca/IBA_RelatorioAnual2016_.pdf.

Instrução Normativa SDA no 13 (24/03/2011). DOU 25/03/2011. https://www.normasbrasil.com.br/norma/instrucao-normativa-13-2011_78540.html.

Janos, D. P. (1976). Vesicular-arbuscular mycorrhizae affect the growth of Bactris gasipaes. Princeps, 61 (1), $12-8$.

Kuroda, K., Kurashita, H., Arata, T., Miyata, A., Kawazoe, M., Nobu, M. K., Narihiro, T., Ohike, T., Hatamoto, M. \& Maki, S. (2020). Influence of Green Tuff Fertilizer Application on Soil Microorganisms, Plant Growth, and Soil Chemical Parameters in Green Onion (Allium fistulosum L.) Cultivation. Agronomy, 10 (7), 929-941.

Kucey, R. M .N. (1983). Phosphate-solubilizing bacteria and fungi in various cultivated and virgin Alberta soils. Canadian Journal of Soil Science, 63 (1), 671-678.

Lagos, A. R. \& Muller B. L. A. (2007). Hotspot Brasileiro - Mata Atlântica. Saúde \& Ambiente em Revista, 2 (2), 35 -45.

Leal, M. L. A., Chaves, J. Da S., Silva, J. A. Da ., Silva, L. S., Soares, R. B. ., Nascimento, J. P. S., Matos, S. M., Teixeira Júnior, D. L. \& Brito Neto, A. F. (2021). Effect of management systems and land use on the population of soil microorganisms . Research, Society and Development, 10 (9), e21910917966.

Lopes, J. S. L., Dias Filho, M. B., Castro, T. H. R. \& Silva, G. B. (2018). Biopromotores e luz no crescimento de Brachiaria brizantha. In: Silva, D. A. S. Agronomia: Elo da Cadeia Produtiva.

Mamede, A. C. P. B. (2015). Atividade Biológica do Fungo Pisolithus microcarpus. Dissertação de mestrado. Universidade Federal de Santa Catarina. Florianópolis, SC.

Marks, G.C. \& Kozlowski, T.T. (1973). Ectomycorrhizae: their ecology and physiology. Academic Press, 444p.

Marleen, I., Sylvie, C. \& Stéphane, D. (2011). Methods for large scale production of AM fungi: past, present and future. Mycorrhiza, 21 (1), 1-16.

Marques, L. C. (2016). Capitalismo e colapso ambiental. Editora Unicamp. 
Martins, D. S., Reis, V. M., Schultz, N., Alves, B. J. R., Urquiaga, S., Pereira, W., Sousa, J. S. \& Boddey, R. M. (2020). Both the contribution of soil nitrogen and of biological $\mathrm{N}_{2}$ fixation to sugarcane can increase with the inoculation of diazotrophic bacteria. Plant and Soil, 454 (1-2), 155-169.

Molina, R. (1977). Ectomycorrhyzal fungi and forestry practice. In: Walters, T. (ed.). Mushrooms and Man, an interdisciplinary aproach to mycology. (Reproduced by the Forest Service, U.S. Department of Agriculture, for official use).

Molina, R. (1981). Ectomycorrhyzal specificity in the genus Alnus. Canadian Journal of Botany, 59 (3), 325-34

Moreira, F. M. S. \& Siqueira, J. O. (2006). Microbiologia e bioquímica do solo. Editora Universidade Federal de Lavras (UFLA), (2a ed.). 726 p.

Muniz, M. F. B., Silva, L. M. \& Blume, E. (2007). Influência da assepsia e do substrato na qualidade de sementes e mudas de espécies florestais. Revista Brasileira de Sementes, 29 (1), 140-146.

Oliveira, T. E., Resende, M. L., Florentino, L. A. \& Silva, N. C. D. (2020). Antagonistic activity of rhizobacteria in the inhibition of the fungus Pseudocercospora griseola (Sacc.). Científica, 48 (4), 363-366.

Oliveira, J. P. C., Correia, D. B., Verçosa, C. J., Figueroa, M. E. V., Cabral, C. P., Vitor, L. N. A., Santos, A. F., Martins, A. S., Teixeira, L. M., Pereira, G. G., Anunciação, J. A. O., Pereira, F. D., Vasconcelos, J. M. P. B. L., Silva, A. S. O., Fernandes, N. De S., Oliveira, P. S., Sampaio, N. K. S., Santos, R. H. L., Barros, J. E. L. \& Santos, M. A. F. (2021). Inappropriate land use and its impacts on the degradation of áreas. Research, Society and Development, 10 (12), e35101219948, 2021.

Ortega-Larrocea, M. P., Xoconostle-Cázares, B., Maldonado-Mendonza, I. E., Carrilo-Gonzáles, R., Hernández-Hernández, J., Garduño, M., López-Meyer, M., Gómez-Flores, L. \& Gonzáles-Chávez, M. C. A (2010). Plant and fungal biodiversity from metal mine wastes under remediation at Zimapan, Hidalgo, Mexico. Environmental Pollution, 158 (5), 1922-1931.

Pasqualini, D. (2013). Inoculação de fungos micorrízicos arbusculaes e bactérias solubilizadoras de fosfato como alternativas para agricultura familiar e recomposição florística. Tese (doutorado) - Universidade do Estado de Santa Catarina, Centro de Ciências Agroveterinárias, Programa de Pós- Graduação em Manejo do Solo, Lages, 178 p.

Poggiani, F., Simões, J. W., Mendes Filho, J. M. A. \& Morais, A. L. (1981). Utilização de espécies de rápido crescimento na recuperação de áreas degradadas. Piracicaba, IPE F, 1981. 25p. (Série Técnica, 2(4).

Ribeiro, V. P., Marriel, I. E., Sousa, S. M. De, Lana, U. G. De P., Mattos, B. B., Paiva, C. A. O. \& Gomes, E. A. (2018). Endophytic Bacillus strains enhance pearl millet growth and nutrient uptake under low-P. Brazilian Journal of Microbiology, 49 (1), 40-46.

Sales, N. L. P. (1992). Efeito da população fúngica e do tratamento químico no desempenho de sementes de ipê-amarelo, ipê-roxo e barbatimão. 1992. Dissertação (Mestrado em Fitossanidade) - Escola Superior de Agricultura, Universidade Federal, Lavras, 89 p.

Santachiara, G., Salvagiotti, F. \& Rotundo, J. L. (2019). Nutritional and environmental effects on biological nitrogen fixation in soybean: A meta-analysis. Field Crops Research, 240 (1), 106-115.

Santos, L. C. (2006). Efeito do cobre na população de bactérias e fungos do solo, associação ectomicorrízica e no desenvolvimento de mudas de Eucalipto e Canafístula. Dissertação (Mestrado em Ciências do Solo) - Universidade Federal de Santa Maria, Santa Maria, RS, 88p.

Schlemper, T. R. \& Stürmer, S. L. (2014). On farm production of arbuscular mycorrhizal fungi inoculum using lignocellulosic agrowastes. Mycorrhiza, 24 (8), 571-580.

Siqueira, J. P. D. (2003). Os conflitos institucionais da gestão florestal no Brasil - um benchmarking entre os principais produtores florestais internacionais. Tese (Doutorado em Engenharia Florestal) - Setor de Ciências Agrárias, Universidade Federal do Paraná, Curitiba, 182 p.

Smith, S. E., Read, D. J. \& Harley, J. L. (1997). Mycorrhizal symbiosis. (2a ed.), Academic, 605 p.

Souza. A. M. (2000). Diversidade fenotípica e genotípica de isolados de Pisolithus spp. Dissertação (Mestrado) - UFLA. 107 p.

Souza, P. V. D., Carniel, E., Kröeff Schmitz, J. A \& Silveira, S. V. (2005). Influência de substratos e fungos micorrízicos arbusculares no desenvolvimento do porta-enxerto Flying Dragon (Poncirus trifoliata, var. monstruosa Swing.). Revista Brasileira de Fruticultura, 27 (2), $285-287$.

Souza, L., Silva, G. \& Oliveira, V. (2004). Eficiência de fungos ectomicorrízicos na absorção de fósforo e na promoção do cre scimento de eucalipto. Pesquisa Agropecuária Brasileira, 39 (4), 349-355.

Sylvia, D. M. \& Jarstfer, A. G. (1994). Production of inoculum and inoculation with arbuscular mycorrhizal fungi. In: Robson, A. D. \& Malajczuk, N. (eds). Management of mycorrhizas in agriculture, horticulture and forestry. Dordrecht: Academic Publishers. p. 231-238.

Terra, A. B. C., Souza, F. R. C., Mantovani, J. R., Rezende, A. V. \& Florentino, L. A. (2019). Physiological characterization of diazotrophic bacteria isolated from Brachiaria brizantha rhizosphere. Revista Caatinga, 32 (3), 658-666.

Trappe, J. M. (1987). Phylogenetic and ecologic aspects of mycotrophy in the Angiosperms from na evolutionary standpoint. In: Safir, G. R. (Ed.). Ecophysiology of VA mycorrhizal plants. Boca Raton: CRC, p. 5-25.

Verma, S. C., Ladha, J. K. \& Tripathi, A. K. (2001). Evaluation of plant growth promotion and colonization ability of endophy tic diazotrophs from deep water rice. Journal of Biotechnology, 91 (4), 127-141.

Vessey, J. K. (2003). Plant growth promoting rhizobacteria as biofertilizers. Plant and Soil, 255 (1), 571-586.

Zandavalli, R. B., Sturmer, S. 1. \& Dillenburg, L. R. (2008). Riqueza de espécies de fungos micorrízicos arbusculares em florestas com Araucaria no sul do Brasil. Hoehnea, 35 (1), 63-68.

Zobel, R. W., Tredice, P. D. \& Torrey, J. G. (1976). Methods for growing plants aeroponically. Plant Physiology, 57 (2), $344-346$. 